\title{
PENGARUH LIVELIHOOD ASSETS TERHADAP RESILIENSI NAFKAH RUMAHTANGGA PETANI PADA SAAT BANJIR DI DESA SUKABAKTI KECAMATAN TAMBELANG KABUPATEN BEKASI
}

\author{
The Influence of Livelihood Assets in Livelihood Resilience Farm Household at \\ Sukabakti Village, Bekasi
}

\author{
Fatimah Azzahra*) dan Arya Hadi Dharmawan
}

Departemen Sains Komunikasi dan Pengembangan Masyarakat, Fakultas Ekologi Manusia, IPB

*Email: fatimahazzahra594@gmail.com

\begin{abstract}
The purpose of this study was to analyze the use of livelihood assets by farm household and their influence on the level of farm household's resilience at Sukabakti village. Farm household was divided into two areas that was farm household in the flood area and farm household in the not flood area. In addition, the research also view structure a living that on farm, off farm, and non farm built by farm household in two areas. This study combined quantitative approach using questioner method and qualitative approach using depth interview method. The result of these study explained livelihood assets used by farmers in Sukabakti village highly influencing their resilience's level. There are significant differences between the two areas where farm household in the flood area are dominated in non farm sector, while in the not flood area are dominated on farm and off farm sector. The level of household's resilience in the not flood area is higher than farm household in the flood area.
\end{abstract}

Keywords: farm household, livelihood assets, resilience

\begin{abstract}
ABSTRAK
Tujuan dari penelitian ini adalah untuk menganalisis pemanfaatan livelihood assets rumahtangga petani dan pengaruh livelihood assets pada tingkat resiliensi rumahtangga petani dalam kondisi krisis di Desa Sukabakti. Rumah tangga petani dibagi menjadi dua daerah, yaitu rumahtangga petani di daerah banjir dan rumahtangga petani di daerah tidak banjir. Selain itu, penelitian ini juga melihat struktur kehidupan dalam on farm, off farm, dan non pertanian yang dibangun oleh rumah tangga petani di dua daerah. Penelitian ini menggunakan kombinasi pendekatan kuantitatif dengan menggunakan metode kuesioner dan pendekatan kualitatif dengan menggunakan metode wawancara mendalam. Hasil penelitian ini menjelaskan livelihood assets yang digunakan oleh petani di desa Sukabakti yang sangat mempengaruhi tingkat resiliensi mereka. Ada perbedaan yang signifikan antara dua daerah di mana rumahtangga petani di daerah banjir didominasi sektor non pertanian, sementara di daerah tidak banjir didominasi pada sektor on farm dan off farm. Tingkat resilensi rumahtangga petani di daerah tidak banjir lebih tinggi dari pada rumahtangga petani di daerah banjir.
\end{abstract}

Kata kunci: livelihood assets, resiliensi, rumahtangga petani

\section{PENDAHULUAN}

\section{Latar Belakang}

Masyarakat yang mengusahakan sebuah lahan pertanian sebagai sumber nafkahnya disebut sebagai petani. Menurut Turasih (2012) pertanian tidak hanya sebagai usaha bagi petani, tetapi merupakan cara hidup (way of life) sehingga tidak hanya menyangkut aspek ekonomi saja tetapi juga aspek sosial dan kebudayaan. Meskipun demikian, Mubyarto (1995) dalam Turasih (2012) menjelaskan bahwa dari segi ekonomi pertanian, berhasil tidaknya produksi petani dan tingkat harga yang diterima oleh petani untuk hasil produksinya merupakan faktor yang sangat mempengaruhi perilaku dan kehidupan petani.

Menurut Dharmawan (2007), dua basis nafkah yang saling mengisi yaitu sektor pertanian dan non-pertanian menyebabkan keterlekatan warga komunitas pedesaan kepada dua sektor tersebut secara khas. Setiap lapisan menggandakan kegiatan ekonominya di dua sektor tersebut. Setiap individu, atau rumah tangga memiliki modal nafkah yaitu modal finansial, modal fisik, modal alam, modal manusia, dan modal sosial dalam memanfaatkan peluang nafkah.

Lima modal tersebut dijelaskan Ellis (2000) sebagai livelihood assets yaitu modal alam, modal fisik, modal manusia, modal finansial, dan modal sosial. Sektor pertanian merupakan sektor yang cukup rentan terhadap berbagai gejala alam seperti perubahan musim, cuaca, dan bencana alam. Oleh karena itu, berhasil atau tidaknya suatu lahan pertanian merupakan hal yang tidak pasti karena berbagai faktor gejala alam yang mempengaruhinya tersebut. Suatu 
kondisi krisis dapat dialami oleh rumahtangga petani akibat gagal panen yang disebabkan oleh kondisi alam yang tidak dapat diprediksi. Pada saat kondisi krisis tersebut, rumahtangga petani memiliki suatu derajat resiliensi. Konsep resiliensi sosial diperkenalkan oleh Jansen (2007) dalam Cote (2012) sebagai kemampuan kelompok atau masyarakat untuk mengatasi tekanan eksternal dan gangguan sebagai akibat dari perubahan sosial, politik, dan lingkungan. Menurut Holling (1973) dalam Cote (2012) ketahanan ekologi selain dipahami sebagai jumlah waktu yang diperlukan untuk kembali ke sistem awal yang stabil, tetapi juga kapasitas sistem untuk menyerap gangguan sementara tetap mempertahankan populasi dan variabel yang sama.

Resiliensi yang dimiliki oleh rumahtangga petani ketika menghadapi suatu krisis dapat dipahami sebagai kemampuan rumahtangga tersebut untuk kembali ke kondisi normal. Salah satu permasalahan yang dihadapi petani yaitu bencana alam. Desa Sukabakti merupakan salah satu desa di Kecamatan Tambelang, Kabupaten Bekasi. Berdasarkan data dari dinas pertanian Kabupaten Bekasi, Kecamatan Tambelang merupakan kecamatan dengan produktivitas pertanian terendah yaitu sebesar 47,06 Kwintal/Hektar selama tahun 2013. Kondisi geografis Desa Sukabakti yaitu bentuk tanah yang menurun dari wilayah timur ke wilayah barat desa. Sehingga hal yang unik adalah wilayah timur Desa Sukabakti tidak terendam banjir pada saat musim hujan, namun wilayah barat Desa Sukabakti selalu terendam banjir pada saat musim hujan. Oleh karena itu, komunitas petani di wilayah barat Desa Sukabakti dan komunitas petani di wilayah Timur Desa Sukabakti menjadi populasi sasaran dalam penelitian ini.

\section{Perumusan Masalah}

Berdasarkan latar belakang tersebut, menarik untuk diteliti:

1. Sejauhmana pemanfaatan livelihood assets oleh rumahtangga petani di dua komunitas?

2. Bagaimana resiliensi rumahtangga petani dalam kondisi krisis di dua komunitas?

\section{Tujuan Penelitian}

Tujuan penelitian dirumuskan sebagai berikut:

1. Menganalisis pemanfaatan livelihood assets rumahtangga petani di dua komunitas

2. Menganalisis resiliensi rumahtangga petani dalam kondisi krisis di dua komunitas

\section{Kegunaan Penelitian}

Penelitian ini memiliki kegunaan sebagai berikut:

1. Bagi akademisi, penelitian ini diharapkan menjadi proses pembelajaran dalam memahami fenomena sosial di lapangan. Selain itu, penelitian ini diharapkan dapat memberikan literatur mengenai topik yang terkait.

2. Bagi masyarakat, penelitian ini diharapkan dapat memberikan gambaran mengenai kondisi desa, serta memaparkan berbagai livelihood assets dan pemanfaatannya oleh rumahtangga petani dalam bertahan hidup, sehingga menjadi referensi bagi rumahtangga lainnya untuk mengetahui seberapa besar kontribusi masing-masing modal nafkah.

3. Bagi pemerintah, penelitian ini diharapkan menjadi suatu saran dalam memberikan informasi dan data untuk pembuatan kebijakan yang terkait dengan pertanian, pencemaran sungai, dan bencana alam.

\section{PENDEKATAN TEORITIS}

\section{Tinjauan Pustaka}

\section{Pengertian Nafkah}

Menurut Ellis (2000), nafkah adalah mata pencaharian terdiri dari aset (alam, manusia, finansaial, dan modal sosial), kegiatan, dan akses masuk (dimediasi oleh lembaga dan hubungan sosial) yang bersama-sama menentukan hidup yang diperoleh oleh individu atau rumahtangga. Sedangkan, Diversifikasi mata pencaharian pedesaan didefinisikan sebagai proses dimana rumah tangga pedesaan membangun sebuah portofolio yang semakin beragam dengan kegiatan dan aset dalam rangka untuk bertahan hidup dan untuk meningkatkan standar hidup mereka. Terdapat lima modal yang dijelaskan Ellis sebagai livelihood asset yaitu modal alam, modal fisik, modal manusia, modal finansial, dan modal sosial. Modal alam merujuk pada sumber daya alam dasar (tanah, air, pohon) yang menghasilkan produk yang digunakan oleh populasi manusia untuk kelangsungan hidup mereka. Modal fisik merujuk pada aset-aset yang dibawa ke dalam eksistensi proses produksi ekonomi, sebagai contoh, alat-alat, mesin, dan perbaikan tanah seperti teras atau saluran irigasi. Modal manusia merujuk pada tingkat pendidikan dan status kesehatan individu dan populasi. Modal finansial merujuk pada persediaan uang tunai yang dapat diakses untuk membeli barang-barang konsumsi atau produksi, dan akses pada kredit dapat dimasukkan ke dalam kategori ini. Modal sosial merujuk pada jaringan sosial dan asosiasi di mana orang berpartisipasi, dan dari mana mereka dapat memperoleh dukungan yang memberikan kontribusi terhadap penghidupan mereka. Menurut Dharmawan (2007), pada mahzab Bogor, strategi penghidupan dan nafkah pedesaan dibangun selalu menunjuk ke sektor pertanian (dalam arti luas). Dalam posisi sistem nafkah yang demikian, basis nafkah rumahtangga petani adalah segala aktivitas ekonomi pertanian dan ekonomi non-pertanian.

Karakteristik sistem penghidupan dan nafkah yang dicirikan oleh bekerjanya dua sektor ekonomi, juga sangat ditentukan oleh sistem sosial-budaya setempat. Terdapat tiga elemen sistem sosial terpenting yang sangat menentukan bentuk strategi nafkah yang dibangun oleh petani kecil dan rumahtangganya. Ketiga elemen tersebut tersebut adalah: (1) infrastruktur sosial (setting kelembagaan dan tatanan norma sosial yang berlaku), (2) struktur sosial (setting lapisan struktur agrarian, struktur demografi, pola hubungan pemanfaatan ekosistem lokal, pengetahuan lokal), (3) supra-struktur sosial ( setting ideologi, etika-moral ekonomi, dan sistem nilai yang berlaku).

\section{Konsep Resiliensi}

Konsep resiliensi sosial diperkenalkan oleh Jansen (2007) dalam Cote (2012) sebagai kemampuan kelompok atau 
masyarakat untuk mengatasi tekanan eksternal dan gangguan sebagai akibat dari perubahan sosial, politik, dan lingkungan. Menurut Cote (2012), permasalahan dalam mendefinisikan konsep resiliensi dalam sistem sosial-lingkungan adalah keterbatasan menganalisis tradeoff dan keputusan manajemen aspek tata kelola dalam bingkai sempit model prioritas sosial dan lingkungan. Oleh karena itu, untuk memahami resiliensi, pendekatan yang digunakan dengan menjawab pertanyaan-pertanyaan normatif untuk menganalisis kapasitas adaptif sistem ekologi sosial yang melibatkan stakeholder pada berbagai skala, dengan beberapa pendekatan untuk penilaian sumber daya dan kepemimpinan yang berbeda, dan hubungan jaringan sosial heterogen yang mendasari dan membentuk praktek manajemen yang membentuk resiliensi tersebut.

Menurut Holling (1973) dalam Cote (2012) ketahanan ekologi selain dipahami sebagai jumlah waktu yang diperlukan untuk kembali ke sistem awal yang stabil, tetapi juga kapasitas sistem untuk menyerap gangguan sementara tetap mempertahankan populasi dan variabel yang sama. Oudenhoven et al. (2011) memberikan gambaran mengenai praktik- praktik hubungan manusia dengan alam, karakteristik ekologi (keanekaragaman hayati, habitat, jasa ekosistem) dan aspek-aspek sosial (lembaga, jaringan, pendidikan) merupakan indikator sosial-ekologi pada resiliensi dalam suatu sistem konservasi.

Menurut Bekers et al. (2003) seperti dikutip Hanazaki et al. (2012) resiliensi menawarkan lensa yang digunakan untuk memahami tekanan dan guncangan dalam sistem ekologi sosial, dan secara khusus dinamika mata pencaharian masyarakat pedesaan yang bergantung pada sumberdaya.

Selain itu, menurut Walker et al. (2004) seperti dikutip Hanazaki et al. (2012), resiliensi didefinisikan sebagai kapasitas sistem untuk menyerap gangguan dan reorganisasi sementara ketika mengalami perubahan sehingga masih mempertahankan fungsi, struktur, identitas, dan umpan balik, yang pada dasarnya sama.

Ketahanan adalah kapasitas sistem ekologi sosial untuk terus berubah dan beradaptasi, namun tetap dalam ambang batas kritis (Gunderson dan Holling, 2002) dalam (Hanazaki et al, 2012). Oleh karena itu, resiliensi menjadi ciri kemampuan sistem untuk menghadapi perubahan.

\section{Hipotesis Penelitian}

Hipotesis penelitian ini yaitu diduga tingkat pemanfaatan livelihood asset yang terdiri dari modal manusia, alam, fisik, finansial dan sosial yang dilakukan rumahtangga mempengaruhi menjawab tujuan penelitian. Data yang diperoleh melalui kuesioner diolah dengan menggunakan microsoft excel 2010 sebelum dimasukan ke perangkat lunak SPSS for Windows versi 19 untuk mempermudah pengolahan data. Uji statistik yang digunakan tingkat resiliensi rumahtangga petani Yn yakni uji regresi linier untuk melihat pengaruh antara variabel yang akan diuji. Data kualitatif diperoleh dari wawancara mendalam dan observasi.

\section{Kerangka Pemikiran}

Pertanian merupakan salah satu sumber nafkah unggulan bagi masyarakat pedesaan. Rumahtangga petani memiliki lima modal dalam memanfaatkan sumber nafkahnya yaitu modal alam, modal fisik, modal manusia, modal sosial, dan modal finansial. Kelima modal tersebut akan mempengaruhi tingkat resiliensi rumahtangga dalam menghadapi guncangan atau kondisi krisis. Resiliensi dapat dilihat dari waktu yang dibutuhkan rumahtanga kembali ke keadaan awal ketika terjadi krisis dan jumlah cara penyesuaian yang dilakukan rumahtangga ketika terjadi krisis.

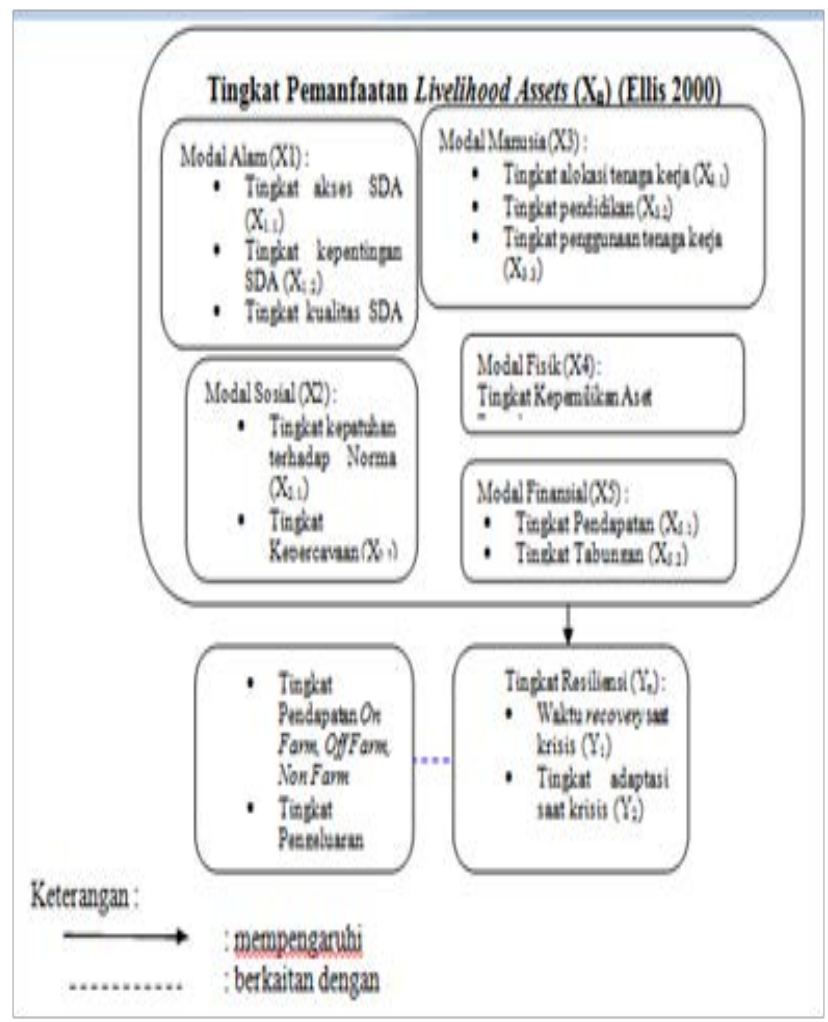

Gambar 1. Kerangka Pemikiran

\section{PENDEKATAN LAPANG}

Penelitian ini dilakukan di Desa Sukabakti, Kecamatan Tambelang, Kabupaten Bekasi, Propinsi Jawa Barat. Pemilihan lokasi penelitian dilakukan dengan mempertimbangkan kondisi pertanian di daerah tersebut, serta kondisi krisis yang dialami oleh rumahtangga petani di daerah tersebut karena bencana banjir. Penelitian ini akan difokuskan pada dua komunitas petani, yakni komunitas petani di wilayah banjir dan komunitas petani di wilayah tidak banjir. Data kedua komunitas akan dibandingkan, sehingga terlihat variasi data yang akan diperoleh.

Populasi sasaran dalam penelitian ini adalah seluruh petani di wilayah banjir dan wilayah tidak banjir, Kecamatan Tambelang,Kabupaten Bekasi. Dalam pendekatan kuantitatif responden dipilih untuk menjadi target survey. Unit analisis dalam penelitian ini adalah rumah tangga petani. Pemilihan responden dilakukan dengan teknik pengambilan sampel acak sederhana (Simple Random Sampling). Teknik ini dipilih karena populasi yang menjadi sasaran bersifat homogen, terdapat daftar kerangka sampling serta keadaan populasi tidak terlalu tersebar secara geografis (Singarimbun dan Effendi, 1989). Jumlah sampel yang akan dijadikan responden berjumlah enam puluh orang (tiga puluh di 
wilayah banjir dan tiga puluh di wilayah tidak banjir). Jumlah ini dirasa cukup untuk memenuhi reliabilitas dan validitas data yang dihasilkan.

Untuk menganalisis data yang telah terkumpul dilakukan reduksi data, yakni pemilihan, pemusatan perhatian, serta penyederhanaan terhadap data sehingga disajikan secara deskriptif untuk mendukung dan memperkuat analisis kuantitatif. Gabungan dari data kuantitatif dan kualitatif diolah dan dianalisis untuk disajikan dalam bentuk tabulasi silang, teks naratif, matriks, bagan dan gambar. Tahap terakhir yaitu menarik kesimpulan sesuai dengan rumusan masalah dan tujuan penelitian.

\section{PROFIL MASYARAKAT DESA SUKABAKTI}

Desa Sukabakti berbatasan secara langsung dengan Desa Sukarahayu di sebelah Selatan. Di sebelah timur berbatasan dengan Desa Sukamulya, di sebelah barat berbatasan dengan Desa Sukadaya, dan di sebelah utara berbatasan dengan Desa Sukabudi dan Desa Sukawijaya. Luas total wilayah Desa Sukabakti yaitu 787.074 hektar. Luas tersebut dibagi menjadi dua yaitu luas areal persawahan dan luas areal darat. Luas areal persawahan yaitu 749.024 hektar. Luas tersebut merupakan kedua terluas untuk areal persawahan se-Kecamatan Tambelang. Kemudian luas darat di Desa Sukabakti yaitu 38.050 Hektar.

Kondisi geografis Desa Sukabakti yaitu bentuk tanah yang menurun dari wilayah timur ke wilayah barat desa, sehingga hal yang unik adalah wilayah timur Desa Sukabakti tidak terendam banjir pada saat musim hujan, namun wilayah barat Desa Sukabakti selalu terendam banjir pada saat musim hujan. Oleh karena itu, komunitas petani di wilayah barat Desa Sukabakti dan komunitas petani di wilayah timur Desa Sukabakti menjadi populasi sasaran dalam penelitian ini.

Sebagian besar masyarakat Desa Sukabakti merupakan penduduk asli. Walaupun terdapat pendatang, hanya sebagian kecil dan berasal dari Desa tetangga. Masyarakat Desa Sukabakti mayoritas merupakan suku betawi. Bahasa yang dipakai sehari-hari sangat khas yaitu perpaduan antara Bahasa Jawa dan Bahasa Sunda dengan logat betawi yang sangat kental. Hal tersebut disebabkan lokasi Kabupaten Bekasi berada di wilayah perbatasan antara Jakarta dan Jawa Barat. Selain itu, banyak dipengaruhi oleh pendatang dari Jawa tengah dan Jawa Timur.

Sebagian besar masyarakat Desa Sukabakti berprofesi sebagai petani. Petani dalam hal ini adalah petani pemilik lahan maupun buruh tani. Petani yang memiliki lahan sempit di Desa Sukabakti disebut sebagai petani gurem. Petani yang memiliki lahan yang cukup luas disebut sebagai majikan. Majikan sawah dapat bekerja sendiri maupun memperkerjakan orang lain untuk mengelola sawahnya dengan sistem bagi hasil (maro).

Petani yang tidak memiliki lahan bekerja mengelola sawah majikan yang disebut sebagai bujang sawah atau ada pula yang bekerja sebagai kuli cangkul. Bujang sawah tersebut mengelola sawah majikan dengan sistem maro. Sedangkan pendapatan yang diterima oleh seorang bujang sawah yaitu hasil panen dikurangi modal "nyawah" kemudian dibagi dua antara majikan dan bujang sawahnya. Sistem perekonomian tersebut sudah menjadi bagian dari budaya masyarakat Desa Sukabakti.

\section{Ketersediaan Modal Nafkah Rumahtangga Petani Di Wilayah Banjir}

Rumahtangga Petani di wilayah banjir dibagi menjadi tiga lapisan yaitu lapisan bawah, lapisan menengah dan lapisan atas. Pembagian lapisan tersebut berdasarkan tingkat pendapatan dari masing-masing rumahtangga petani. Setiap lapisan petani memiliki kecenderungan terhadap pemanfaatan modal nafkah yang berbeda. Pembagian lapisan tersebut bertujuan untuk mengetahui sejauh mana pemanfaatan modal nafkah yang dilakukan rumahtangga petani lapisan bawah, lapisan menengah, dan lapisan atas. Kecenderungan pemanfaatan modal tertentu akan berdampak pada tumpuan utama rumahtangga petani dalam melakukan aktivitas nafkahnya. Jika modal yang menjadi tumpuan tersebut terganggu maka rumahtangga petani akan semakin rentan ketika berada dalam kondisi krisis.

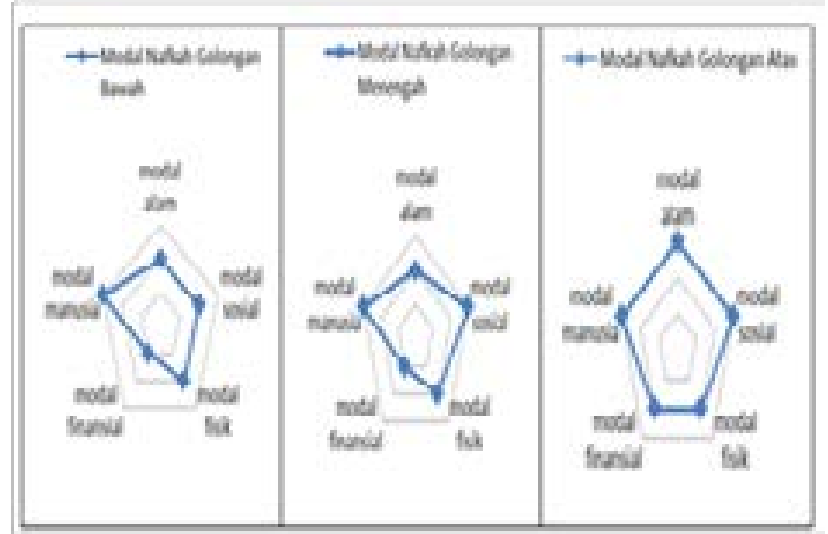

Gambar 2. Pemanfaatan modal nafkah berdasarkan lapisan rumahtangga petani di wilayah banjir, Desa Sukabakti tahun 2013 - 2014

Berdasarkan Gambar 2 di atas, dapat lapisan bawah 40 persen merupakan petani gurem yaitu lahan sawahnya kurang dari 0,25 diketahui basis modal nafkah yang digunakan oleh asing-masing lapisan rumahtangga petani di wilayah banjir. Rumahtangga petani hektar. Rumahtangga petani yang berada di lapisan bawah memiliki tingkat pendapatan yang paling rendah. Tingkat pendapatan rumahtangga petani dibagi berdasarkan data emik yang diolah dengan kurva sebaran normal. Rata-rata rumahtangga petani lapisan bawah memiliki pendapatan kurang dari Rp 28 juta setiap tahunnya. Pendapatan tersebut merupakan akumulasi dari sektor pertanian dan non pertanian. Petani lapisan bawah di wilayah banjir berjumlah 10 rumahtangga.

Modal manusia merupakan modal nafkah yang paling tinggi nilainya bagi rumahtangga petani lapisan bawah. Salah satu komponen modal manusia yaitu tingkat penggunaan tenaga kerja rumahtangga. Petani lapisan bawah yang mayoritas dalah petani gurem membutuhkan lebih dari satu anggota keluarga untuk membantu pekerjaan di sawah. Ketika menandur atau perawatan padi, kepala keluarga dibantu oleh istri dan anaknya. Namun, ketika memanen petani akan membutuhkan banyak tenaga kerja dari luar. Modal manusia dalam petani lapisan menengah juga bernilai tinggi. Salah satu komponen modal manusia yaitu tingkat keterampilan yang dimiliki 
kepala keluarga. Rumahtangga petani lapisan menengah kebanyakan melakukan pola nafkah ganda, sehingga keterampilan mereka tidak hanya sebatas pertanian. Ketika sawah dan perumahan mereka ering dilanda banjir, petani lapisan menengah melakukan aktivitas nafkah lain seperti berdagang, menjadi buruh bangunan, bekerja di pasar sebagai kuli panggul, menjadi buruh bangunan, service hp dan migrasi ke luar Kabupaten.

Modal manusia petani lapisan atas bernilai tinggi. Hal ini disebabkan tiga komponen modal manusia yang dimiliki oleh rumahtangga petani lapisan atas bernilai tinggi yaitu jumlah anggota keluarga yang bekerja, tingkat penggunaan tenaga kerja, dan tingkat keterampilan kepala keluarga. Kebanyakan petani lapisan atas adalah petani pemilik lahan dengan sawah yang cukup luas. Para petani tersebut menjadi majikan dengan sistem maro (bagi hasil), sehingga penggunaan tenaga kerja bernilai tinggi. Para petani yang memarokan sawahnya, juga bekerja di sektor non pertanian seperti menjadi supir truk luar kota dan manjadi karyawan pabrik.

Modal alam bagi rumahtangga petani lapisan bawah bernilai sedang. Hal ini disebabkan banjir yang selalu datang setiap tahun dan merendam lahan pertanian mereka sehingga sulit jika hanya bergantung pada sektor pertanian. Banjir juga merusak sawah para petani hingga mereka harus mengulang menandur hingga tiga sampai empat kali sampai banjir benar-benar surut. Modal alam yang dimiliki oleh petani lapisan menengah bernilai sedang. Struktur nafkah petani lapisan menengah lebih banyak off farm daripada on farm. Artinya, petani lapisan menengah bukan petani pemilik lahan melainkan hanya buruh tani. Hal ini sesuai dengan modal manusia petani lapisan menengah yang lebih banyak mengandalkan sektor non farm. Modal alam rumahtangga petani lapisan atas bernilai tinggi. Hal ini dikarenakan petani lapisan atas memiliki lahan yang cukup luas. Sebagian besar petani tidak hanya mengandalkan dari sumberdaya alam sawah saja, namun mereka juga memiliki kebun-kebun sayur dan buah yang hasilnya dapat dijual. Ketika produktivitas sawah rendah karena banjir dan hama wereng, petani lapisan atas dapat dengan leluasa mengebunkan sawah mereka sehingga tetap ada penghasilan dari sektor pertanian. Modal sosial rumahtangga petani lapisan bawah termasuk dalam kategori sedang. Pada komponen tingkat kekuatan jaringan, beberapa petani masih aktif dalam berbagai kegiatan kelompok tani yang diadakan oleh pemerintah desa. Para petani juga sangat antusias apabila terdapat bantuan berupa bibit gratis dan traktor.

Ketika petani mengalami gagal panen akibat banjir, pengurus kelompok tani akan mendata besar kerugian yang dialami oleh masing-masing petani yang akan diajukan ke pemerintah desa atau ke Penyuluh Pertanian Lapang (PPL). Rumahtangga petani memiliki keterbukaan dan saling membantu apabila sedang dalam kondisi krisis kepada tetangga atau sanak saudara di wilayah tersebut. Ketika sedang dalam kondisi krisis rumahtangga petani memiliki kepercayaan yang tinggi untuk meminta bantuan terhadap saudara dan kerabat, sebagian kecil juga percaya terhadap pemerintah Desa Sukabakti.

Modal sosial merupakan modal nafkah yang memiliki nilai tinggi yang dimiliki oleh rumahtangga petani lapisan menengah. Komponen yang paling membedakan antara rumahtangga petani lapisan menengah dengan rumahtangga petani lapisan bawah yaitu tingkat kekuatan jejaring. Sebagian besar petani di lapisan menengah selain aktif sebagai anggota kelompok tani, mereka juga memiliki organisasi lain di luar Desa. Organisasi atau kelompok tersebut sesuai dengan pekerjaan mereka di sektor non farm, seperti kelompok pedagang sayur, perserikatan kuli panggul di pasar, kelompok pemulung rongsokan dan sebagainya. Kelompok-kelompok tersebut juga dapat membantu rumahtangga ketika terjadi krisis seperti pinjaman uang. Pada komponen tingkat kepatuhan dan tingkat kepercayaan petani lapisan menengah tidak terlalu berbeda dengan rumahtangga petani lapisan bawah. Modal sosial rumahtangga petani lapisan atas tidak jauh berbeda dengan petani lapisan menengah yaitu bernilai tinggi.

Modal fisik yang dimiliki petani lapisan bawah termasuk kategori sedang. Wilayah yang selalu terendam banjir setiap musim hujan membuat rumahtangga petani tidak memiliki banyak aset rumahtangga yang berharga. Rumah mereka dibangun secara sederhana dan banyak yang hanya beralaskan tanah. Perabot rumahtangga juga hanya seperlunya saja. Selain itu, para petani mengaku banyak ternak mereka seperti kambing yang mati ketika banjir karena kekurangan makanan sehingga mereka tidak memiliki ternak lagi. Sedangkan infrastruktur jalan menuju lokasi wilayah banjir tersebut sudah sangat rusak dan membahayakan serta tidak terdapat penerangan ketika malam hari. Modal fisik rumahtangga petani lapisan menengah bernilai sedang. Aset rumahtangga yang dimiliki hanya sederhana dan seperlunya. Rumahtangga lapisan menengah lebih memilih aset seperti perhiasan yang menempel di badan sebagai barang investasi mereka.

Modal fisik rumahtangga petani lapisan atas bernilai sedang. Walaupun pendapatan rumahtangga petani lapisan atas tinggi, namun aset rumahtangga tidak bersifat mewah. Aset rumahtangga petani lapisan atas lebih banyak dalam bentuk emas. Para petani lapisan atas juga memiliki ternak yang mereka titipkan di saudara atau kerabat yang berada di wilayah tidak banjir dengan sistem maro.

Modal finansial merupakan modal paling rendah yang dimanfaatkan oleh rumahtangga petani lapisan bawah wilayah banjir. Hampir seluruh petani lapisan bawah tidak memiliki tabungan berupa uang yang disimpan di rumah maupun di bank. Sebagian besar istri petani bergabung dalam kelompok- kelompok pinjaman yang diadakan oleh bank keliling dengan bunga yang sangat besar. Hal ini sudah berlangsung bertahun-tahun, namun para istri petani tersebut mengaku tidak ada pilihan lain selain berhutang ke bank keliling untuk biaya pendidikan dan kesehatan anggota keluarga. Keadaan ini ditambah produktivitas pertanian yang rendah namun tidak ada aset seperti ternak yang dapat dijual karena bencana banjir.

Modal finansial yang dimiliki rumahtangga lapisan menengah bernilai rendah. Hal ini dikarenakan rumahtangga tidak mempunyai tabungan berupa uang. Namun, mereka lebih memilih untuk membeli emas yang dapat dijual sewaktu-waktu. Selain itu, setiap rumahtangga petani lapisan menengah pasti memiliki hutang. Modal finansial petani lapisan atas lebih tinggi satu tingkat dibandingkan petani lapisan bawah dan petani lapisan menengah.

Modal finansial petani lapisan atas bernilai sedang. Hal 
ini disebabkan beberapa petani lapisan atas memiliki tabungan berupa uang yang disimpan di bank. Beberapa petani memiliki tabungan untuk berangkat haji ke Mekah. Sebagian besar petani menabung untuk menginvestasikan uang mereka jika sewaktu-waktu dibutuhkan dapat diambil di bank cabang Bancong. Sedangkan untuk tingkat hutang, beberapa petani lapisan atas memiliki hutang terhadap bank swasta maupun bank keliling.

\section{Ketersediaan Modal Nafkah Rumahtangga Petani Di Wilayah Tidak Banjir}

Rumahtangga petani di wilayah tidak pembagian tingkat pendapatan tersebut berdasarkan data emik yang ada dalam masyarakat. Pemanfaatan modal nafkah oleh masingmasing lapisan rumahtangga petani banjir dibagi ke dalam tiga lapisan berdasarkan tingkat pendapatan rumahtangga yaitu lapisan dapat dilihat pada gambar di bawah ini.

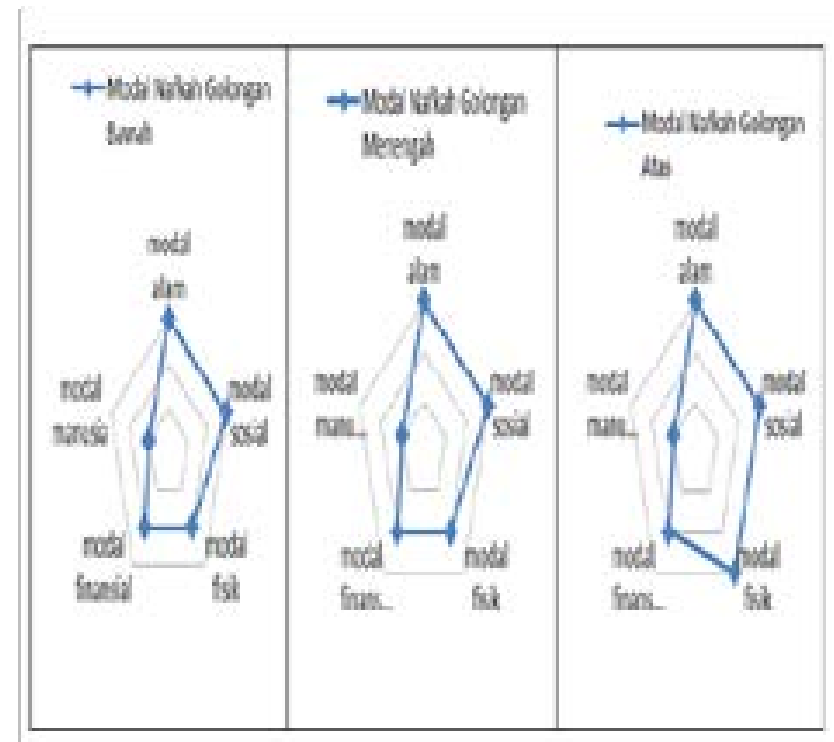

Gambar 3. Pemanfaatan modal nafkah oleh lapisan rumahtangga petani di wilayah tidak banjir, Desa Sukabakti tahun $2013-2014$

Rumahtangga petani lapisan bawah di menengah sama dengan rumahtangga petani wilayah tidak banjir memiliki pendapatan di bawah Rp 20,3 juta per tahun. Rumahtangga petani lapisan bawah mengandalkan pendapatan dari sektor off farm dan non farm. Artinya, rumahtangga petani lapisan bawah di wilayah tidak banjir hanya buruh tani dengan sistem maro. Sedangkan sektor non farm yang digeluti kebanyakan adalah berdagang. Rumahtangga petani lapisan bawah paling banyak jumlahnya dari total rumahtangga petani wilayah tidak banjir yaitu 11 rumahtangga.

Rumahtangga petani lapisan menengah di wilayah tidak banjir berjumlah 10 rumahtangga. Rumahtangga petani lapisan menengah merupakan petani dengan penghasilan antara Rp 20,3 juta hingga $\mathrm{Rp} 43,2$ juta per tahun. Rumahtangga petani lapisan menengah di wilayah tidak banjir memiliki persentase struktur nafkah yang setara antara on farm, off farm, dan non farm. Pemanfaatan modal nafkah rumahtangga petani lapisan bawah, lapisan menengah, dan lapisan atas.
Modal manusia rumahtangga petani lapisan bawah di wilayah tidak banjir bernilai rendah. Hal ini disebabkan pendidikan petani rendah, rata-rata petani hanya berpendidikan SD atau tidak tamat SD. Selain itu, dalam rumah tangga petani lapisan bawah di wilayah tidak banjir kebanyakan hanya kepala keluarga yang bekerja serta penggunaan tenaga kerja yang rendah karena petani hanya sebagai buruh tani. Modal manusia rumahtangga petani lapisan menengah di wilayah tidak banjir juga bernilai rendah. Modal manusia petani lapisan atas bernilai rendah karena petani yang berpendidikan rendah. Petani pemilik sawah juga langsung mengerjakan sawahnya sendiri atau tidak melakukan sistem maro. Selain itu, dalam rumahtangga petani lapisan atas hanya kepala keluarga atau satu anggota keluarga lain yang bekerja.

Modal alam rumahtangga petani di wilayah tidak banjir bernilai tinggi. Pertanian di wilayah tidak banjir cukup rentan karena adanya Organisme Pengganggu Tanaman (OPT) padi seperti wereng, kupu-kupu, dan tikus. Hal ini membuat para petani pemilik sawah banyak yang mengebunkan sawah mereka. Para petani lapisan bawah di wilayah tidak banjir banyak yang bekerja pada sektor off farm kebun sayuran, yaitu menjadi buruh di kebunkebun sayur. Rumahtangga petani lapisan bawah tidak hanya mengandalkan satu sumberdaya alam saja yaitu sawah namun juga kebun.

Modal sosial rumahtangga petani lapisan bawah di wilayah banjir juga bernilai tinggi. Penyebabnya tidak jauh berbeda dengan rumahtangga petani di wilayah banjir. Para petani aktif dalam berbagai kegiatan kelompok tani. Selain itu, hubungan kekerabatan dan tingkat kepercayaan masih tinggi karena sebagian besar penduduk merupakan penduduk asli. Modal sosial rumahtangga petani lapisan menengah di wilayah banjir bernilai tinggi. Penyebabnya tidak jauh berbeda dengan rumahtangga petani di wilayah banjir. Hubungan kekerabatan dan tingkat kepercayaan masih tinggi karena sebagian besar penduduk merupakan penduduk asli. Modal sosial petani lapisan atas tidak jauh berbeda dengan petani lapisan bawah dan menengah karena jaringan yang dimiliki oleh rumahtangga petani yaitu jaringan pada kelompok tani dan kelompok non pertanian di bidang aktivitas nafkah non farm mereka. Selain itu, mayoritas penduduk merupakan penduduk asli sehingga hubungan kekerabatan masih sangat tinggi.

Modal fisik rumahtangga petani lapisan bawah dan menengah termasuk sedang. memiliki aset rumahtangga. Modal fisik yang dimiliki rumahtangga petani lapisan atas di wilayah banjir termasuk tinggi. Hal ini dikarenakan kepemilikan aset rumahtangga yang tinggi. Bahkan terdapat satu rumahtangga petani lapisan atas yang memiliki traktor. Selain itu, rumahtangga petani lapisan atas di wilayah tidak banjir banyak yang memiliki ternak seperti kambing, ayam, bebek, dan nila. Modal finansial rumahtangga petani lapisan bawah dan menengah di wilayah tidak banjir bernilai sedang. Hal ini disebabkan masyarakat masih tidak memprioritaskan menabung berupa uang. Selain itu, sama seperti rumahtangga di wilayah banjir, rumahtangga lapisan bawah di wilayah tidak banjir juga memiliki ketergantungan yang kuat terhadap bank keliling. Namun, beberapa rumahtangga memilih saving berupa perhiasan.

Modal finansial petani lapisan atas di wilayah tidak banjir bernilai sedang. Sebagian petani sudah memiliki 
tabungan berupa yang disimpan di rumah maupun di bank swasta. Namun, rumahtangga petani juga memiliki ketergantungan yang kuat terhadap bank keliling.

\section{Analisis Modal Nafkah di Dua Komunitas}

Rumahtangga petani di wilayah banjir dan wilayah tidak banjir memiliki basis nafkah dan kecenderungan pada ketergantungan modal nafkah yang berbeda. Perbedaan ini akan mempengaruhi ketahanan atau resiliensi rumahtangga petani ketika terjadi krisis. Basis nafkah rumahtangga petani di dua komunitas dapat di lihat pada gambar di bawah ini.

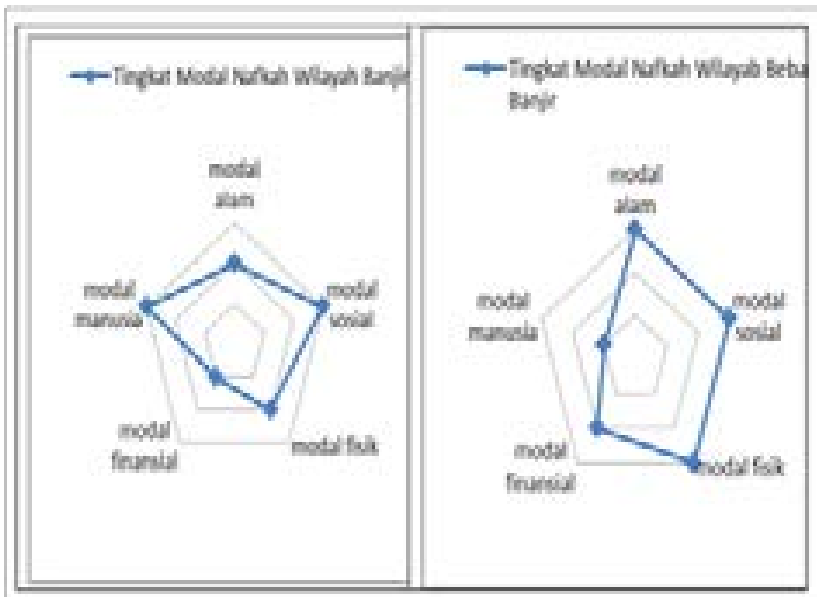

Gambar 4. Basis nafkah rumahtangga petani di dua komunitas, Desa Sukabakti tahun 2013 - 2014

\section{Faktor-Faktor yang Mempengaruhi Resiliensi Rumahtangga Petani di Dua Komunitas}

Faktor-faktor yang mempengaruhi tingkat resiliensi diuji dengan analisis regresi linier, alpha ditentukan sebesar 20 persen atau 0,2 artinya toleransi kesalahan pada uji regresi tersebut adalah 20 persen dan kebenarannya adalah 80 persen. Berdasarkan uji tersebut, modal nafkah yang mempengaruhi tingkat resiliensi rumahtangga petani di wilayah banjir adalah modal manusia, modal sosial, modal alam, modal fiansial dan modal fisik. Komponen dari modal nafkah tersebut dipecah sehingga dihasilkan faktor-faktor yang mempengaruhi resiliensi rumahtangga petani di wilayah banjir yaitu tingkat keterampilan kepala keluarga, tingkat kekuatan jaringan, tingkat hutang, tingkat akses terhadap SDA, tingkat kepentingan SDA, tingkat kepemilikan aset, dan tingkat pendapatan.

Berdasarkan hasil analisis regresi, diketahui tingkat signifikan variabel yang mempengaruhi resiliensi rumahtangga petani di wilayah banjir. Tingkat keterampilan kepala keluarga merupakan komponen dari modal manusia. Tingkat keterampilan kepala keluarga menunjukkan keterampilan yang dimiliki kepala keluarga selain bertani yang mempengaruhi aktivitas nafkahnya.

Variabel tingkat keterampilan kepala keluarga signifikan dengan tingkat resiliensi rumahtangga petani karena di wilayah banjir banyak yang bekerja di sektor non farm. Oleh karena itu, kepala keluarga di wilayah banjir memiliki keterampilan selain bertani seperti menjadi buruh pabrik, buruh panggul, dan berdagang. Hal tersebut disebabkan sektor pertanian di wilayah banjir sangat tidak menguntungkan. Semakin banyak keterampilan yang dimiliki kepala keluarga dalam mencari nafkah maka pendapatan rumahtangga akan meningkat sehingga rumahtangga petani di wilayah banjir dapat mencapai resilien ketika terjadi krisis.

Tingkat kekuatan jaringan merupakan komponen modal sosial. Tingkat kekuatan jaringan dapat dilihat dari jumlah kelompok atau organisasi yang diikuti oleh rumahtangga. Kelompok atau organisasi tersebut dapat membantu rumahtangga petani ketika dalam kondisi krisis. Tingkat kekuatan jaringan signifikan dengan tingkat resiliensi rumahtangga petani di wilayah banjir karena rumahtangga petani di wilayah banjir merupakan anggota kelompok dimana ia bekerja seperti kelompok buruh pabrik, serikat buruh panggul dan sebagainya. Kelompok-kelompok tersebut memberikan bantuan kepada rumahtangga petani dalam melakukan aktivitas nafkahnya dan dalam menghadapi kondisi krisis. Semakin banyak kelompok atau organisasi yang diikuti makan rumahtangga petani di wilayah banjir akan semakin resilien.

Tingkat hutang merupakan bagian dari modal finansial. Hutang merupakan salah satu cara yang digunakan oleh rumahtangga petani di wilayah banjir ketika menghadapi kondisi krisis. Rumahtangga petani yang melakukan strategi hutang dapat dikatakan memiliki jumlah pengeluaran yang lebih tinggi daripada jumlah pendapatan. Tingkat hutang signifikan dengan dengan tingkat resiliensi rumahtangga petani di wilayah banjir dan merupakan faktor dengan nilai koefisien terkecil sehingga paling mempengaruhi resiliensi rumahtangga petani di wilayah banjir. Besarnya hutang yang dimiliki dan lama waktu pengembaliannya akan berdampak pada kestabilan keuangan rumahtangga petani di wilayah banjir. Rumahtangga petani yang memiliki hutang dengan jumlah yang besar dan waktu pengembalian yang cukup lama memiliki kerentanan yang tinggi.

Tingkat akses SDA dan tingkat kepentingan SDA merupakan komponen dari modal alam. Tingkat akses SDA dilihat dari jumlah sumber daya alam yang dapat diakses oleh rumahtangga petani. Tingkat akses SDA signifikan dengan tingkat resiliensi rumahtangga petani di wilayah banjir karena SDA yang dapat diakses oleh rumahtangga petani hanya sungai dan sawah. Hal tersebut disebabkan bencana banjir merusak SDA sehingga semakin sedikit jumlah SDA yang dapat diakses oleh rumahtangga petani. Berdasarkan hal tersebut diketahui bahwa kerentanan rumahtangga petani disebabkan oleh semakin sedikitnya jumlah SDA yang dapat mereka akses.

Tingkat kepentingan SDA merupakan derajat kepentingan SDA terhadap pendapatan rumahtangga petani. Tingkat kepentingan SDA signifikan dengan tingkat resiliensi rumahtangga petani di wilayah banjir karena sungai dan sawah di wilayah banjir memiliki tingkat kepentingan yang tinggi bagi pendapatan pertanian rumahtangga petani. Sungai yang dinamakan Kali Goban, merupakan satu-satunya pengairan yang dapat mengairi sawah petani. Namun, ketika musim hujan tiba, Kali Goban akan meluap dan menyebabkan bencana banjir di sawah dan pemukiman warga.

Tingkat pendapatan rumahtangga petani merupakan akumulasi dari pendapatan on farm dan pendapatan off farm rumahtangga petani di wilayah banjir dalam waktu satu tahun. tingkat pendapatan signifikan dengan tingkat 
resiliensi rumahtangga petani di wilayah banjir karena jumlah pendapatan yang lebih besar dari jumlah pengeluaran akan membentuk saving capacity. Saving capacity tersebut akan meningkatkan resiliensi rumahtangga petani di wilayah banjir. Lapisan atas yang memiliki tingkat pendapatan paling tinggi memiliki resiliensi paling tinggi pula.

Tingkat kepemilikan aset rumahtangga merupakan komponen dari modal fisik. Tingkat kepemilikan aset rumahtangga di wilayah banjir lebih rendah dibandingkan di wilayah tidak banjir. Tingkat kepemilikan aset rumahtangga di wilayah banjir signifikan dengan tingkat resiliensi karena bencana banjir dapat merusak kepemilikan asset rumahtangga petani. Selain aset rumahtangga, ternak juga merupakan modal fisik yang dapat dijual sewaktu-waktu ketika rumahtangga petani dalam kondisi krisis. Beberapa responden mengatakan bahwa ternak mereka mati karena kehabisan makanan pada saat bencana banjir terjadi. Berdasarkan fakta tersebut, modal fisik yang bernilai rendah dapat meningkatnya kerentanan dan menurunkan resiliensi rumahtangga petani di wilayah banjir.

Berdasarkan uji analisis regresi di wilayah tidak banjir dengan alpha 20 persen, modal nafkah yang mempengaruhi tingkat resiliensi rumahtangga petani di wilayah tidak banjir adalah modal manusia, modal sosial, modal fisik, modal alam, dan tingkat pendapatan. Komponen dari modal nafkah tersebut dipecah sehingga dihasilkan faktorfaktor yang mempengaruhi resiliensi rumahtangga petani di wilayah banjir yaitu tingkat alokasi tenaga kerja, tingkat penggunaan tenaga kerja, tingkat kepatuhan pada norma, tingkat kepemilikan aset rumahtangga, tingkat kualitas SDA, dan tingkat pendapatan. Berikut pemaparan faktorfaktor yang mempengaruhi tingkat resiliensi rumahtangga petani di wilayah tidak banjir.

Tingkat alokasi tenaga kerja dan tingkat penggunaan tenaga kerja merupakan komponen dari modal manusia. Tingkat alokasi tenaga kerja dilihat dari jumlah anggota keluarga yang bekerja. Tingkat alokasi tenaga kerja signifikan terhadap tingkat resiliensi rumahtangga petani di wilayah tidak banjir karena sebagian besar rumahtangga hanya mengandalkan sektor pertanian sebagai sumber pendapatan mereka. Adanya anggota keluarga lain yang bekerja pada sektor non farm akan meningkatkan resiliensi rumahtangga petani. Oleh karena itu, modal manusia yang rendah menyebabkan rendahnya resiliensi rumahtangga petani di wilayah tidak banjir.

Tingkat penggunaan tenaga kerja merupakan jumlah tenaga kerja yang dipekerjakan oleh rumahtangga petani. Tingkat penggunaan tenaga kerja signifikan terhadap tingkat resiliensi rumahtangga petani karena rumahtangga petani di wilayah tidak banjir didominasi oleh sektor on farm dan off farm. Petani pemilik lahan yang berasal dari lapisan atas bertindak sebagai "majikan". Petani yang menggarap sawah majikan disebu sebagai "bujang sawah". Sistem bagi hasil yang diterapkan yaitu sistem maro. Semakin banyak penggunaan tenaga kerja di wilayah tidak banjir akan semakin meningkatkan resiliensi rumahtangga petani pada saat kondisi krisis.

Tingkat kepatuhan pada norma merupakan komponen dari modal sosial. Tingkat kepatuhan pada norma signifikan terhadap tingkat resiliensi rumahtangga petani di wilayah tidak banjir karena rumahtangga petani di wilayah tidak banjir memiliki keterbukaan dan keterlekatan yang kuat dengan lingkungan sosialnya. Saudara dan tetangga merupakan modal sosial utama ketika rumahtangga sedang dalam kondisi krisis. Salah satu yang mendukung hal tersebut adalah fakta bahwa mayoritas penduduk merupakan penduduk asli. Kekuatan modal sosial dapat meningkatkan resiliensi rumahtangga petani di wilayah tidak banjir.

Tingkat kepemilikan aset rumahtangga merupakan komponen dari modal fisik. Kepemilikan aset rumahtangga petani di wilayah tidak banjir lebih tinggi daripada rumahtangga petani di wilayah banjir. Tingkat kepemilikan aset rumahtangga di wilayah tidak banjir signifikan terhadap tingkat resiliensi rumahtangga petani karena bencana banjir tidak merusak atau menghancurkan modal fisik tersebut. Ternak merupakan salah satu aset utama rumahtangga petani di wilayah tidak banjir. Ternak dan hasil ternak seperti telur dapat dijual sewaktu-waktu ketika rumahtangga membutuhkan uang dalam kondisi krisis. Kepemilikan ternak tersebut meningkatkan resiliensi rumahtangga petani di wilayah tidak banjir.

Secara keseluruhan modal alam berpengaruh secara linier terhadap tingkat resiliensi rumahtangga petani di wilayah tidak banjir. Tingkat kualitas SDA merupakan komponen dari modal alam yang paling berpengaruh terhadap tingkat resiliensi rumahtangga petani di wilayah tidak banjir. Kualitas SDA dalam penelitian ini merupakan kualitas air sungai yang mengairi lahan pertanian warga. Penyebab utama kerentanan rumahtangga petani di wilayah tidak banjir merupakan serangan hama pengganggu tanaman sehingga mengakibatkan gagal panen selama satu tahun berturut-turut. Petani sangat yakin bahwa hama pengganggu lahan pertanian mereka dapat tumbuh subur dan tidak terkendali akibat sungai yang mengairi lahan pertanian mereka tercemar limbah pabrik. Sungai yang bernama Kali Bancong tersebut mengalir dari daerah industri Cikarang, Kabupaten Bekasi menuju desa-desa di Kecamatan Tambelang. Resiliensi rumahtangga petani di wilayah banjir menjadi rendah karena tingkat kualitas SDA rendah.

Tingkat pendapatan rumahtangga petani di wilayah tidak banjir lebih rendah daripada rumahtangga petani di wilayah banjir. Rumahtangga petani di wilayah banjir masih sangat bergantung pada sektor pertanian. Tingkat pendapatan signifikan terhadap tingkat resiliensi rumahtangga petani di wilayah tidak banjir karena sektor pertanian yang sangat rentan karena serangan hama akan mempengaruhi pendapatan yang diterima rumahtangga petani. Produktivitas pertanian menurun sehingga pendapatan petani menurun. Hal tersebut dapat meningkatkan kerentanan dan menurunkan resiliensi rumahtangga petani di wilayah tidak banjir.

\section{PENUTUP}

\section{Kesimpulan}

1. Modal manusia di wilayah banjir lebih tinggi daripada di wilayah tidak banjir. Hal ini disebabkan oleh komponen tingkat alokasi tenga kerja dan tingkat keterampilan kepala keluarga di wilayah banjir lebih tinggi daripada di wilayah tidak banjir. Kepala keluarga di wilayah banjir memiliki keterampilan di sektor non pertanian dibandingkan kepala keluarga 
di wilayah tidak banjir yang hanya bergantung pada sektor pertanian. Modal sosial di wilayah banjir dan tidak banjir sama-sama bernilai tinggi. Hal tersebut disebabkan mayoritas penduduk di kedua wilayah merupakan penduduk asli sehingga hubungan kekerabatan masih sangat tinggi. Terdapat perbedaan tingkat kepemilikan asset rumahtangga yang cukup signifikan antara wilayah banjir dan tidak banjir. Rumahtangga petani di wilayah tidak banjir memiliki tingkat kepemilikan aset rumahtangga yang lebih tinggi daripada rumahtangga petani di wilayah banjir. Hal tersebut disebabkan bencana banjir dapat merusak asset fisik rumahtangga di wilayah banjir. Secara umum, modal finansial di kedua wilayah bernilai rendah. Hal tersebut karena rumahtangga petani di kedua wilayah tidak memiliki tabungan berupa uang. Menabung berupa uang tidak menjadi prioritas rumahtangga. Sedangkan, rumahtangga petani di kedua wilayah memiliki tingkat hutang yang tinggi. Mayoritas responden merupakan nasabah bank keliling. Modal alam di wilayah tidak banjir memiliki nilai yang lebih tinggi daripada rumahtangga petani di wilayah banjir. Hal tersebut disebabkan bencana alam banjir merusak modal alam rumahtangga petani di wilayah banjir.

2. Tingkat resiliensi rumahtangga petani dilihat dari waktu recovery saat krisis dan jumlah cara penyesuaian saat terjadi krisis. Tingkat resiliensi rumahtangga petani di wilayah tidak banjir lebih tinggi dibandingkan rumahtangga petani di wilayah banjir. Hubungan livelihood assets dan tingkat resiliensi dapat dilihat dari pengaruh modal nafkah sebagai variabel $X$ terhadap tingkat resiliensi sebagai variabel Y. Faktor-faktor yang mempengaruhi resiliensi di wilayah banjir yaitu yaitu tingkat alokasi tenaga kerja, tingkat penggunaan tenaga kerja, tingkat kepatuhan pada norma, tingkat hutang, tingkat kepentingan SDA, dan tingkat pendapatan. Sedangkan faktor-faktor yang mempengaruhi tingkat resiliensi rumahtangga petani di wilayah tidak banjir adalah modal sosial, modal fisik, modal alam, dan tingkat pendapatan. Komponen dari modal nafkah tersebut dipecah sehingga dihasilkan faktor-faktor yang mempengaruhi resiliensi rumahtangga petani di wilayah banjir yaitu tingkat kepatuhan pada norma, tingkat kepemilikan asset rumahtangga, tingkat kualitas SDA, dan tingkat pendapatan.

\section{Saran}

1. Pendekatan teknologi dalam pemanfaatan sumber daya alam dalam mengurangi dampak bencana banjir di wilayah banjir Hal tersebut dilakukan untuk menjamin produksi tani sepanjang tahun. Dalam hal ini, akademisi, pemerintah lokal dapat menginisiasi adanya sumber air pertanian yang aman, terjangkau, dan bebas limbah.

2. Pentingnya melakukan upaya advokasi terkait pencemaran sumber air yang merugikan petani. Perusahaan harus bertanggung jawab dan mengimplementasikan kebijakan terkait limbah yang dihasilkan dan dibuang ke sungai.

3. Pentingnya membentuk koperasi atau lembaga keuangan mikro yang mampu mensupport kegiatan pra-pertanian, produksi dan pasca panen sehingga petani memiliki akses modal atau asset lainnya dalam bertani. Selain itu, lembaga keuangan tersebut dapat mengurangi ketergantungan rumahtangga petani terhadap bank keliling.

\section{DAFTAR PUSTAKA}

Cote M, Nightingale AJ. 2012. Resilience thinking meets social theory: Situating social change in socio-ecological systems (SES) research. Progress in Human Gheography. 36(4): 475-489. [Internet]. [dikutip 24 April 2014]. Dapat diunduh dari: sagepub.co.uk/journalsPermissions.nav

Dharmawan AH. 2007. Pandangan Sosiologi nafkah (livelihood sociology) Mazhab Barat dan Mazhab Bogor. Jurnal Sodality . $01 \quad$ (02): 1-24. [Internet]. [dikutip 25 Februari 2014]. Dapat diunduh dari: http://download.Portalgaruda.org/ article.ph p article $=83493 \& \mathrm{val}=223$

Ellis F. 2000. Rural Livelihood and Diversity in Development Countries. New York [US]: Oxford University Press

Hanazaki $\mathrm{N}$ et al. 2012. Livelihood Diversity, Food Security and Resilience among the Caiçara of Coastal Brazil. Hum Ecol

Journal. 41:153-164. [Internet]. [dikutip 24 April 2014]. Dapat diunduh dari: 10.1007/s10745-012-9553-9

Oudenhoven FJW, Mijatovic D, Eyzaguirre PB. 2011. Social-ecological indicators of resilience in agrarian and natural landscapes. Management of Environmental Quality. 22(2): 154-173. [Internet]. [dikutip 24 April 2014]. Dapat diunduh dari: 10.1108/14777831111113356 Singarimbun $M$, Effendi S. 1987. Metode penelitian survai. Jakarta: LP3ES

Turasih, Adiwibowo S. 2012. Sistem nafkah rumah tangga petani kentang di dataran tinggi Dieng (kasus Desa Karangtengah, Kecamatan Batur, Kabupaten Banjarnegara, Provinsi Jawa Tengah). Jurnal Sodality. 06 (02): 196-207. [Internet]. [dikutip 20 September 2014]. Dapat diunduh dari: journal. ipb.ac.id/index.php/sodality/article/ .../4727 